\title{
Jalal al-Din Davani political thought reflection on the leaf of Khamsah of Nezami in the period of Khalil Sultan Aq Qoyunlu
}

\author{
Dr. Masoumeh abachi ${ }^{1}$, Dr. Asghar Fahimifar ${ }^{2}$, Dr. Reza Afhami ${ }^{3}$ \\ ${ }^{I}$ (Assistant professor\& Academic staff, Department of Art and architecture, Shahid Bahonar University, Iran) \\ (Responsible author) \\ ${ }^{2}$ (Associate professor, Department of Art Studies, Tarbiat Modares University, Iran ) \\ ${ }^{3}$ (Associate professor, Department of Art Studies, Tarbiat Modares University, Iran)
}

\begin{abstract}
Check hidden layers in the painting "Alexander War with Russia" of Khamseh of Nizami, belonging to the period of Khalil Sultan announced the existence of political thought in the age of Turkmen Aq Quyunlu in the Shiraz (Iran). It seems political thought of Jalal al-Din Davani caused to Continuity Iranshahri political thought and aesthetic and cultural elements of ancient Persia in this period. The aim of the research is to achieve a different interpretation of the Scene "Alexander war with Russian" with descriptive, analytical approach. The results indicate, this painting has a political strains and beyond its formal aesthetic elements, the implications are profound, leading to political power of Khalil Sultan, through Iranshahri political thought, by influence of the ideas of philosopher of Shiraz school, Jalal al-Din Davani, one of the most political man in the Turkmen court and the Founder of Davanies school placed in Shiraz.
\end{abstract}

Key words:- Political Thought, Khalil Sultan Aq Quyunlu, Jalal al-Din Davani, Khamseh of Nizami

\section{INTRODUCTION}

The main problem in this study is that in the illustrated Khamseh before Khalil Sultan (876- $883 \mathrm{AH} /$ 1471- 1478 AD), the scene of "Alexander War with Russia", not to be illustrated. Authors in this particle intend to find the existential reason of the scene in Khamseh of Aq Quyunlu Turkmens. This manuscript is at the Metropolitan Museum, dating from the late ninth century AH, the number 13.228.9.1. The paintings style of the manuscript is similar to book of Sultan Khalil age. According to the authors, some of this manuscript has political strains, which could be analyzed and interpreted aspacts of Iranshahri political thought and sociapolitical demands of Shiraz and so philosophical ideas in this period. only painting in this Khamseh about Alexander's war in the "Eskandarnameh" of Nezami which is presented in the book is "Alexander War with Russia", that we analyze in this study.

\section{REVIEW OF LITERATURE}

Keshavarz Afshar, Tavoosi and Zeimaran (2011), in an article titled "Iranshahri Political Thought in Persian painting", analyzes the miniatures of Khamse in the Safavid period, which seems to have political content and it refers to the features of ideal King in the ancient Iran, based on Political text. Ahmad (2005) in his article describes the components of the political thought of Iranshahri in the Eskandarnameh of Nizami. Dehbashi (1996) offers an analysis from Jalal -al-Din Davani philosophical and theological ideas, but so far has not been investigated about the political thought of Davani and its reflection in the miniature of Khamseh of Nizami in the age of the Turkmens.

\section{RESEARCH METHODOLOGY}

The research method is descriptive and analytical, using library resources and the Internet. The main goal is to prove that the painting in the lower layer offers a demonstration of political power through political thinking Jalal al-Din Davani (who is influenced by the Iranshahri political thought of ancient persia) indicating a FARAHMAND Shah (Sultan Khalil) and confirmation his power and wisdom to gain the legitimacy.

Other objectives:

1. Recognition the political thinking of the court Khalil Sultan Aq Qoyunlu in the Shiraz

2. The relationship between political thought and its appearance in the art

3. Recognizing icons and symbolic motifs in the image of this study, that indicate the appearance of political thought During the Aq Quyunlu in this painting. 


\section{THE THEORETICAL FRAMEWORK OF RESEARCH}

Javad Tabatabai, Iranian scholars believe that the "Siyasatnameh $\neg$ Nevysy" (or writing texts of policy) is one of the major movement, cased the ancient culture continue in the Islamic period. In his view, the "Siyasatnameh $\neg$ Nevysy" flow is a continuation of "Iranshahri Political Thought" of ancient period (Tabatabai, 2009: 17, 20-21). Siyasatnameh or policies are the most important source of political thought in the Islamic and the authors of them often Minister or Amir (king) were thinking about the power to follow of ancient methods and ways of Iranshahri domination (Tabatabai, 2009: 57). Hence, the most important subject in Political writings ( or Siyasatnameh) is political power and maintain it by governs. Also Khamseh of Nizami is the Policy book, which Nizami Ganjavi challenges the Seljuk king, especially in the Eskandarnameh, and express the desired characteristics ideal king, which is corresponded with the characteristics of ancient kings.

The central concept of Iranshahr political think is concerned with the theory of ideal charismatic king and concepts of the cosmic struggle between good and evil. Other items associated with the political think including the theory of cosmic sacred order (Asha), the sacred nature of power, Racial splendor of King, three social class, religion continuity with policy, justice and utopian theory (Keshavarz Afshar, tavoosi, Zeimaran,2011: 39). According to Ahmad (1384) only the good king, has the divine splender and the most important feature of ideal king in the mind of Nizami is his justice.

\section{RESULTS AND DISCUSSION}

The reasons for the continuity of ancient art in the Islamic period, especially in painting of the Shiraz school, can be pointed to links between political thinking Iranshahri which is related to the governance of ideal and charismatic king and his divine power, and Policies that maintains the strength of the governor monarchy. Since the Kings know the proud and governmental authority is in the connection and Companion with the scholars and scientists, for this reason, philosopher, judge and scholar of Turkmen, Jalal-al-Din Davani_is appointed to minister by Jahan shah Qarā-quyunlu ( 839- 872 AH/ 1435- 1467 AD), in the Shiraz. He was also highly respected in the Aq $\neg$ quyoonlo period, especially at the court of Sultan Khalil, the ruler of Shiraz and his father Uzun Hasan in the Tabriz. The investigations revealed, Jalal-al-Din resigns from the Ministry of Qarāquyunlu very soon, but acquires a lot of honor and esteem at the Aq Quyunlu court. He writes Ethics of Jalali for Uzun Hasan, with the content of practical ethics and governance practices, with Khalil Recommend. His books include the four virtues of wisdom, courage, modesty and justice, prudence civil and customs of the kingdom, policy and customs of kings, ceremonial duty to elect of kings, Etiquette with people and so on. It seems one of the most important reasons for the success of the government and foreign and domestic policy of Aq Quyunlu is conformity of behavior of kings in this dynasty with the political thoughts of this great scholar. The main discussion of Jalal-al- Din Davani in the civil politic is Justice and following it by the ruling. In his view, social justice is the result of the implementation of the principles of justice by ruling. In the Iranshahri political thinking (that is, the sum of the ancient Iranian ideas on politics, government), divine splendor, justice, wisdom, and courage and power of the king, are the guarantor of the stability of the political system and structure of the kingdom. The political thought moved to the Islamic period and was manifested in the Khamseh of Nizami and Ethics of Jalali. In the Ethics of Jalali, governors should to support the oppressed and take the oppressed in judicial affairs as soon as possible and must have Compassion and stay away from anger. Their goal should be the administration of justice and prefer the forgiveness to justice. Jalal-al-Din believes that King's wisdom is fundamental of politics.

"As is the consistency of the body to nature and consistency of the nature to the spirit and consistency of the spirit to the intellect, the consistency of country to the King and consistency to the politics and the consistency of policy to wisdom" (Davani, 291). The text on the margins of "Alexander war with the Russian army" (Fig 1), which provided to the poem language by Nizami, has all the desired features of Jalal-al- Din Davani in the his book, and it is not without reason, because of the Khamseh (that was written in the 6th century $\mathrm{AH} /$ 12th $\mathrm{AD}$ ), is the political book which is emphasized in the stories on the characteristics of the ideal king, according to ancient traditions. And so Ethics of Jalali is the political book which its author was Iranian minister and Turkmen court judge, whom for The preservation of culture and art and ancient thinking from the foreign Turkmen governments emphasizes the characteristics of the ideal king in this book in accordance with ancient Khodāy-Name and the political books of rulers and ministers, such as Onsor-al-Ma'āli Keykavoūs or Khajeh Nezam-Al-molk and mention the attributes to non-Iranian king ( Khalil Sultan and his father, Uzun Hasan). War between Alexander and the Russians lasted 5 days. This is the story that Alexander crossed the Kipchak and camped beside the river [perhaps the Danube]. Russian Qantal was the ruling ... and brave men came out of the Russian army and so brave military commander of the Alexander's army from Khorezm, Rome and Persia and China. Finally, Alexander went into battle, who saw suddenly a Jockey of the army went to the battlefield and Cast the dust all of the heroes of Russian. The second day of the Jockey destroyed many Russian. On the third day, Russian army fielded a giant... Again the same Jockey came to the battleground and knocked arrows on the giant... but in the end it was caught in the hands of giant. The giant wanted to cut off her head that 
moved aside his helmet and women's hair appeared. The giant was deterred killing the woman and left her with Russian soldiers. In fear of escape his army, Alexander rode the horse that the king of China had given him. He quickly threw a lasso and the giant caught and handed over to prison guards. Alexander organized a celebration for his victory. He had mercy on the giant and ordered the strap open of his tired body and injured. Finally the giant brought to Alexander the girl and after removing her mask, Alexander surprised to see that she is the slave girl who king of China had given him. The first and second day of the war, she attacked the army of the enemy and destroyed many of them. In the third day, Alexander took strap giant (Riyazi, 2006: 217- 219). On the morning of the fourth of war, Alexander decided the war ended, because Belniyas was seen victory on the astrolabe. Alexander got up at dawn and prayed to be victorious over the enemies. ... Finally, the Russian army was defeated. Alexander won the Qantal, the king of the Russians and imprisoned him. Alexander worshiped because he thought God helped him win. After resting and feasting and division of the spoils of victory, Alexander ordered Qantal will free strap. Alexander placed him on the throne and gave him the kingdom of Russians, provided that to be a loyal vassal. Then all Russian prisoners were freed (Riyazi, 2006, 220, 221). In fact, the painting shows the scene of the fight on the fourth day.

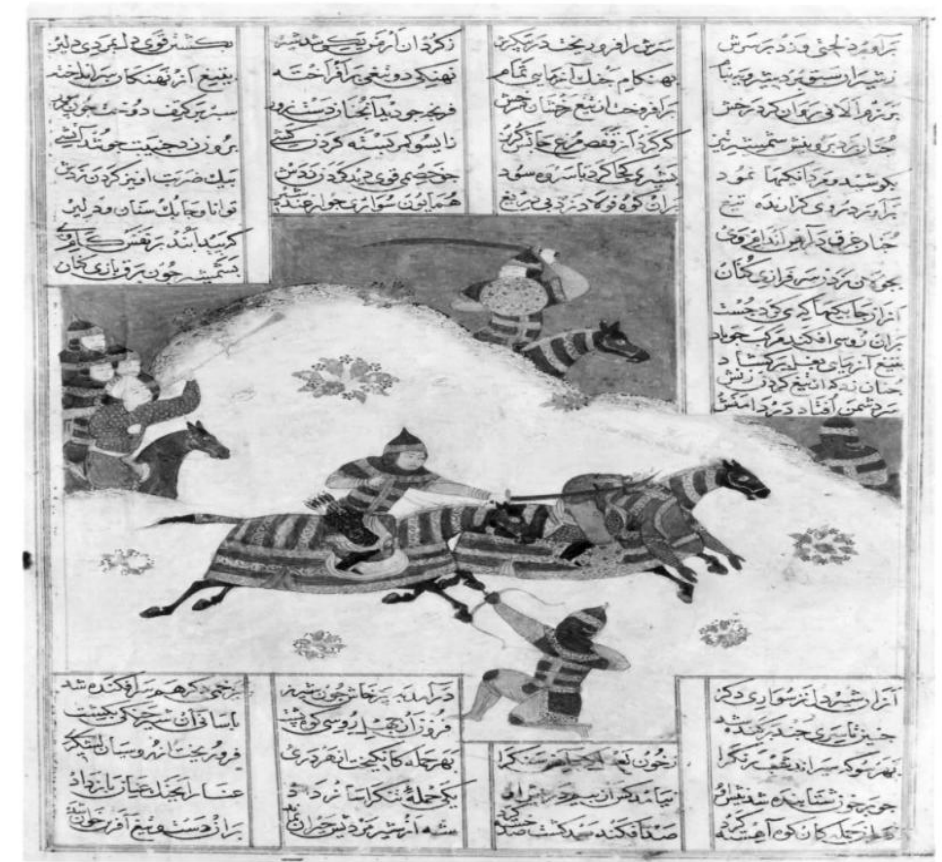

Fig 1. Alexander War with Russia, Khamseh of Nizami, late 9th century AH/ 15 AD, the period of Khalil Sultan, Shiraz. Source: http://www.metmuseum.org/collection

In the analytical approach of the authors in the article to the lyrics that accompany painting, Alexander is a King with theology and with knowledge and insight and compassion, and courageous, just and forgiving the enemy. These criteria are corresponded exactly with the Jalal-al-Din Davani features from ideal king that are mentioned in his book. Alexander, who goes to war at dawn on the fourth day, after prayer to God and finally defeat the enemy. He knows the victory of God and assumes himself like soil in the greatness and power of God. In alongside image, the text of the poem reads: Thanks God, the face was on the earth victory came of God, he was soillt seems painter to depict scenes of Alexander and his attack on the enemy and with the use of some symbols, such as swords, horses, bows and arrows, emphasizes on courage and strength of Alexander and his attack on the enemy.

\section{CONCLUSION}

This research was concerning display power hidden layers in a miniature of Khamseh Nizami of Khalil Sultan Aq Quyunlu period. The result showed that in the beyond of superstructure of "Alexander war with the Russian" painting from this manuscript and poem related with this image, There are multiple hidden layers, not only announce the political thinking of Iranshahri and FARAHMAND King and his power for legitimacy of Sultan Khalil, but also as a political text, it will be given moral lessons, warnings, and necessary training, the impact of political ideas Jalal-al- Din Davani, to the king of age by the painter. Considering the high power image compared with the Word, this painting illustrated to learn lessons of trust and help of God, courage and chivalry, freemen and generosity to the king. emphasis of Jalal-al- Din Davani in the writings on the Iranian and protection of political thinking of the ancient Persia in Turkmen foreign government led to the continuation 
Iranshari political thought in the royal court of the Aq Quyunlu Turkmen. And we see its reflection in the painting, that painter rebuild the ideal, strong and brave Iranians King in the Alexander character on the his battlefield with the Russians by using the iconic motifs.

\section{REFERENCES}

[1] Ahmad, M. 2005, "Iranshahri Political Thought in Alexandernameh of Nizami", Quarterly of Tarbiat Moallem University of Azerbaijan, No. 6 (2), 2005, 11-23.

[2] Davani, J., Lavam-Al-Eshraq FIi Makarem-Al-Ackhlaq (Ethics of Jalali), (No place, No date).

[3] Dabashi, M., Analysis of the philosophical and theological ideas of Jalal-al- Din Mohaghegh Davani, Journal of Kheradnameh Sadra. No. 3, 1996. 4-51.

[4] Keshavarz Afshar, M., Tavoosi, M., Zeimaran, M., (2011), in an article titled Iranshahri Political Thought in Persian painting, Journal of letter of visual and Applied arts, No. 6, 2011, 35- 56.

[5] Riyazi, H. Nizami Ganjavi stories and messages.(Tehran: Haghighat, 2006).

[6] Tabatabai, J., income philosophical history of political thought in Iran, Tenth Edition. (Tehran: Islamic Culture Publications Office. 2009). 